\title{
GROWTH AND YIELD OF AVICENNIA OFFICINALIS (BAEN) L. AND HERITIERA FOMES (SUNDRI) BUCH. HAM. PLANTATIONS ESTABLISHED FROM PLUS TREE SEEDS IN THE WESTERN COASTAL BELT OF BANGLADESH
}

\author{
MD. ABDUL QUDDUS MIAH* AND MD. GOLAM MOULA \\ Plantation Trial Unit Division, Bangladesh Forest Research Institute, \\ Barishal, Bangladesh
}

The mangrove forest is distributed in the inter-tidal region between the sea and the land in the world's tropical and subtropical regions between approximately $30^{\circ} \mathrm{N}$ and $30^{\circ} \mathrm{S}$ latitude (Alongi 2009). Mangrove is among the most productive and biologically important ecosystems of the world because they provide important and unique ecosystems, goods and services to humans, society and coastal and marine systems (Giri et al. 2010). It also performs some important ecological, biophysical and socio-economic functions, including serving as a natural barrier against storms, typhoons, and tsunamis, thus protecting coastal habitats (Latief and Hadi 2007). The forests help stabilize shorelines and reduce the devastating impact of natural calamities like tidal wave surge, cyclones and tsunamis. They also provide breeding and nursing grounds for marine and aquatic species and foods, medicine, fuel and building materials for local communities. Mangrove plantations in the shoreline area leads to rapid accretion because the mangrove roots and pneumatophores effectively slow water movement and act as efficient sediment trappers (Woodroffe 1992) and also could be beneficial for long term coastal protection both to continuous erosion and severe natural hazards. Mangrove species are also good candidates to change the coastal environments, social and ecological situation (Nandy and Ahammad 2012).

Over the last two decades, mangrove forest plantation areas have been increasing in Bangladesh. A total of 0.192 million hectares of accreted land were afforested with mangrove species in the coastal regions till 2013 (Hasan 2013). Plantations are increasing day by day to cover the barren forest land and newly accreted land. Bangladesh is one of the leading countries of coastal afforestation programs with different mangrove species. Afforestation program along the coastal belt was initiated in 1966 with the primary objective to protect the lives and properties of coastal communities from the cyclone and tidal surges by creating mangrove forest cover or green belt in the exposed $710 \mathrm{~km}$ coastal belt (Das and Siddiqi 1985). Subsequently, the objectives of coastal afforestation

*Corresponding author: <maqmiah2009@yahoo.com>. 
were expanded to reclamation and stabilization of newly accreted land and production of timber for fuelwood (Saenger 1987). At the first time of plantation, most commercial mangrove species were tried on newly accreted land periodically inundated by tidal water. Among them, only Sonneratia apetala Buch.-Ham is the most successful and Avicennia officinalis (baen) L. is the second most successful planted species of the coastal mangrove plantations (Siddiqi 2001a). Among the cultivated mangrove species, Avicennia officinalis is about 5\% of the total mangrove plantations (Siddiqi 2001b).

At present, the coastal mangrove plantations are under severe threat due to geomorphic changes, species succession and insect infestation to the S. apetala (Siddiqi 2001a). In most old plantation sites, the forest floor rises up due to heavy sedimentation and resulted less inundation during the full moon. Large scales stem borer attack in S. apetala plantations were observed for a long time (Baksha 1996). The mortality of planted seedlings of this species in the coastal areas is also high (Siddiqi and Das 1988). As a result, gaps are created inside $S$. apetala plantations. Moreover, insufficient regeneration appeared under these plantations due to the rising forest floor, compactness of soil and scarcity of other mangrove species' seedlings. The life cycle of S. apetala is short and the rotation period of felling is about 12-15 years. After harvesting of matured S. apetala trees, there will be no second rotation forests for the sustainability of this coastal forest. Thick and dense vegetation can diminish the height of tides and thus reduces the magnitude of the devastation. The dense forest along the coastline can protect human habitation, lives, properties and crops from extreme climate changes (Islam and Rahman 2015). Tropical mangrove forests have been shown highly productive. Still, the growth and yield of planted mangrove species in Bangladesh are lower than in other South Asian countries such as Thailand's, Indonesia, Malaysia and the Philippines (Hawlader 1999). The main reasons for the low productivity of mangrove species were the use of poor quality seeds and planting stocks (Nandy et al. 2004). The use of improved seed source will always remain an essential factor for achieving maximum yield. Intensive forest management activities will never maximize yields unless supplemented with the use of genetically superior trees and their improved seed sources (Zobel and Talbert 1983). Therefore, the present study was undertaken to assess the growth and yield of Avicennia officinalis and Heritiera fomes plantations from plus tree seed sources with high quality seeds from phenotypically superior trees.

The experiment was laid out in two places of maderbunia char lands under Rangabali islands of Patuakhali districts in 2010. One place was newly accreted (char) lands and another medium raised land. Rangabali is located at latitude $21^{\circ} 92^{\prime} \mathrm{N}$ and longitude $90^{\circ} 45^{\prime}$ E. Soil of the sites is silt-clay-loam. In monsoon, water salinity ranged 3-27 ppt, 
while in the dry season, it ranged from 10-33 ppt (Siddiqi and Khan 1990). Soil salinity also varies remarkably between the monsoon and dry seasons. Soil salinity ranged from 0.3-4.2 dS/m in December and reach its peak in April-May, when average salinity is as high as $9 \mathrm{dS} / \mathrm{m}$ (Hasan 1987). Soil salinity in the monsoon and dry season changed remarkably between 1.5 and $4.0 \mathrm{dS} / \mathrm{m}$. Soil $\mathrm{pH}$ was slightly alkaline and varying between 7.5 and 8.0 (Siddiqi and Khan 2000). The climate is humid. Temperatures ranges between $18^{\circ} \mathrm{C}$ and $32^{\circ} \mathrm{C}$ (Siddiqi 2002). Annual rainfall varies from 2500 to $3000 \mathrm{~mm}$ (Siddiqi 2002). The Bangladesh Forest Research Institute established 50 plus trees of $A$. officinalis species at Rangabali and Char Kukri-Mukri Island for good quality seed sources in the pure stand of Avicennia officinalis experimental plantations. The plus tree of Avicennia officinalis (baen) species was selected from different char lands of Rangabali and Char Kukri-mukri in the year 2000. The plus trees were evaluated by providing the highest score 10 for diameter at breast height (dbh), 15 for individual tree height, 20 for bole form, 15 for branch angle, 10 for branch diameter, 10 for apical dominance, 5 for forking and 10 for individual tree health and 30 for wood properties (Nandy 1989). The score range of selected plus tree of A. officinalis species was from 91 to 106 at char Kukri-Mukri, when the stand was 17 years old. The score range of selected plus tree of A. officinalis at Rangabali sites was between 104 and 122 and the stand was seven years old. Another 45 plus tree of Heritiera fomes (sundri) species established in 2000 at Terabaka, bogi, under shoronkhola range of Sundarbans from natural stands and score was between 96 and 114 .

Seeds of Avicennia officinalis and Heritiera fomes were collected from different selected plus tree seed sources. The seeds were collected during August-September. Seedlings were raised in polybags of size $25 \mathrm{~cm} \times 15 \mathrm{~cm}$ filled with powdered soil and cow dung mixture at a ratio of 3:1. Seedlings were maintained in the nursery for about 10 months. Eight to ten month old polybag seedlings were planted at $1.5 \mathrm{~m} \times 1.5 \mathrm{~m}$ spacing. In each plot, $100(10 \times 10)$ seedlings were planted. The experiment was laid out in Randomized Complete Block Design (RCBD) with 3 replications. The seedlings of Avicennia officinalis species were planted in newly accreted land and Heritiera fomes seedlings planted in under keora forest as an under planting at char maderbunia of Rangabali island. Experimental data on tree survival, height, diameter at breast height (dbh), bole height, and crown diameter, and branch number were collected in August 2018 when the plantation stands seven years old. The wood volume of standing trees was calculated following Avicennia officinalis volume table (Latif et al. 1994). All these data were analyzed using Minitab statistical package. Analysis of variance (ANOVA) was used to 
determine the effect of plantations with plus tree seed sources on tree height, diameter and wood volume.

The growth performance of Avicennia officinalis and Heritiera fomes planted in 2010 in the western coastal belt of Bangladesh are shown in Table 1. The highest survival was found $46 \%$ and $40 \%$ for plus tree seed sources and mass collection seed sources of Avicennia officinalis, respectively. The highest height, the diameter of breast height, crown diameter and bole height was found $12.75 \mathrm{~m}, 15.45 \mathrm{~cm}, 7.39 \mathrm{~m}$ and $6.80 \mathrm{~m}$ for plus tree and $9.29 \mathrm{~m}, 9.96 \mathrm{~cm}, 4.00 \mathrm{~m}$, and $3.65 \mathrm{~m}$ for plus tree seed and mass collection seed sources, respectively. Great wood volume was found $7.78 \mathrm{~m}^{3} / \mathrm{ha} / \mathrm{yr}$ and 1.80 $\mathrm{m}^{3} / \mathrm{ha} / \mathrm{yr}$ for plus tree seed sources and mass collection seed sources, respectively, in Avicennia officinalis species (Table 1).

Table 1. Growth performance of Avicennia officinalis and Heritiera fomes planted in 2010 at Rangabali islands from different seed sources.

\begin{tabular}{|c|c|c|c|c|c|c|c|c|}
\hline $\begin{array}{l}\text { Name of } \\
\text { species }\end{array}$ & Seed sources & $\begin{array}{c}\text { Survival } \\
(\%)\end{array}$ & $\begin{array}{l}\text { Height } \\
(\mathrm{m})\end{array}$ & $\begin{array}{l}\text { Dbh } \\
(\mathrm{cm})\end{array}$ & $\begin{array}{l}\text { Mean annual } \\
\text { height } \\
\text { increment } \\
\text { (m) }\end{array}$ & $\begin{array}{l}\text { Crown } \\
\text { Dia }(m)\end{array}$ & $\begin{array}{l}\text { Bole } \\
\text { height } \\
\text { (m) }\end{array}$ & $\begin{array}{c}\text { Wood } \\
\text { volume } \\
\left(\mathrm{m}^{3} / \mathrm{ha} / \mathrm{yr}\right)\end{array}$ \\
\hline \multirow{2}{*}{$\begin{array}{l}\text { Avicennia } \\
\text { officinalis }\end{array}$} & Plus tree seeds & $35.00 \mathrm{a}$ & $12.75 \mathrm{a}$ & $15.45 \mathrm{a}$ & 1.83 & $7.39 \mathrm{a}$ & $6.80 \mathrm{a}$ & $7.78 \mathrm{a}$ \\
\hline & $\begin{array}{l}\text { Mass collection } \\
\text { seeds }\end{array}$ & $28.50 \mathrm{~b}$ & $9.29 b$ & $9.96 \mathrm{~b}$ & 1.33 & $4.00 \mathrm{~b}$ & $3.65 b$ & $1.80 \mathrm{~b}$ \\
\hline \multirow{2}{*}{$\begin{array}{l}\text { Heritiera } \\
\text { fomes }\end{array}$} & Plus tree seeds & 46.00 & 2.56 & 0.17 & $0.36 \mathrm{~m}$ & - & 1.72 & - \\
\hline & $\begin{array}{l}\text { Mass collection } \\
\text { seeds }\end{array}$ & 40.00 & 1.21 & - & $0.17 \mathrm{~m}$ & - & 0.58 & - \\
\hline
\end{tabular}

The highest survival, height, and dbh were found $46 \%, 2.56 \mathrm{~m}$ and $0.17 \mathrm{~cm}$ for plus tree seeds sources and $40 \%$ and $1.21 \mathrm{~m}$ was found for mass collection seed sources of Heritiera fomes, respectively (Table 1). In the present study, the result significantly greater in plus tree seed sources than mass collection seed sources of Heritiera fomes species when the stand was seven years old.

In comparison with other experimental plantations conducted by Bangladesh Forest Research Institute, growth of Avicennia officinalis in 19 years old highest height was $13.52 \mathrm{~m}$, dbh $32.16 \mathrm{~cm}$, bole height $4.71 \mathrm{~m}$, crown diameter $4.74 \mathrm{~m}$ and highest wood volume found $10.04 \mathrm{~m}^{3} / \mathrm{ha} / \mathrm{yr}$ (Miah et al. 2014). Another plantation conducted by Forest Department at char kashem under the Rangabali island height was $13.15 \mathrm{~m}$, dbh 28.96 $\mathrm{cm}$, bole height $4.71 \mathrm{~m}$, crown diameter $4.59 \mathrm{~m}$ and wood volume $5.73 \mathrm{~m} / \mathrm{ha} / \mathrm{yr}$ found in the age of 21 years old Avicennia officinalis stand (Miah et al. 2014). In the present 
study, the height, dbh, bole height, and crown diameter of Avicennia officinalis for plus tree seeds were found significantly greater, followed by mass collection seeds. Wood production was also significantly much higher for plus tree seeds, followed by mass collection seeds. The growth increment and yield were much higher for plus tree seeds of Avicennia officinalis at the age of seven years in coastal forest of Bangladesh.

In the present study growth of $H$. fomes species was found satisfactory in comparison to other established plantation in the coastal belts of Bangladesh. Siddiqi and Khan (1990) was found mean annual height increment from $0.27 \mathrm{~m}$ to $0.70 \mathrm{~m}$ in the 11-14 years old plantations of $H$. fomes plantations and present study mean annual height increment was found $0.36 \mathrm{~m}$. The result revealed that seed sources are an important factor for tree growth and their yield. So, the use of improved seed sources from established plus tree provide significant growth and yield with the ability to withstand extreme climatic conditions in the coastal belt.

Avicennia officinalis and Heritiera fomes species are the important mangrove species for coastal plantation. They play a significant role in the established accreted char land, moderately raised char land and enrich forest vegetation of the man-made coastal forest of Bangladesh. These two species are planted using plus tree seed sources for getting maximum growth and timber production. The improved seed sources can enhance these species growth performance and their adaptability to vulnerable coastal areas. Therefore, now practice to plantations with plus tree seed sources can be raised using these types of seed sources for achieving significant gain from the coastal mangrove ecosystem. This, however, an interim report, and the comprehensive one will be available after a few years.

\section{References}

Alongi, D.M. 2009. Introduction of in the energetic of mangrove forest. Springer Science and Business Media BV. New York. p. 177.

Baksha, M.W. 1996. Behole borer infestation in coastal plantations in Bangladesh and possible management options, Wallacena 77: 17-20.

Das, S. and N.A. Siddiqi. 1985. The Mangroves and Mangrove Forests of Bangladesh. Mangrove Silviculture Division. Bulletin No. 2, Chittagong: Bangladesh Forest Research Institute, p. 142.

Giri, C., E. Ochieng, L.L. Tieszen, Z. Zhu, A. Singh, T. Loveland, J. Masek and N. Duke. 2010. Status and distribution of mangrove forests of the world using earth observation satellite data. Global Ecology and Biogeography, (Global Ecol. Biogeogr.), pp. 1-6 .

Hassan, D.Z. 2013. Plants in Mangroves and Coastal Afforestation in Bangladesh. Dewan House Publisher, Ukilpara, Naogaon. pp. 164.

Hasan, M.M. 1987. Preliminary report on coastal afforestation sites. In: Drigo R, Latif MA, Chowdhury JA, Shaheduzzaman M (eds.), The Maturing Mangrove Plantations of the Coastal Afforestation Project. FAO/UNDP Project, BGD/85/085. Field Document No. 2, Mohakhali, Dhaka: Bangladesh Forest Department, pp. 64-66. 
Hawlader, N.I. 1999. Forest Resources Management Project. Mid-Term Review, Ministry of Environment and Forest, Dhaka. pp. 103.

Islam, S.A. and M.M. Rahman. 2015. Coastal afforestation in Bangladesh to combat climate change induced hazards. Journal of Science Technology Environment Informatics, vol. 14. No. 1, pp. 13-25.

Latif, M.A., S. Das, M.F. Rahman and J.A. Chowdhury. 1994. Tree Volume Tables for Baen (Avicennia officinalis) in the Coastal Plantations of Bangladesh. Bulletine 8, Forest Inventory Division, Chittagong: Bangladesh Forest Research Institute, pp. 21-32.

Latief, H. and S. Hadi. 2007. The role of forests and trees in protecting coastal areas against tsunamis, paper presented at the Regional Technical Workshop on Coastal Protection in the Aftermath of the Indian Ocean Tsunami What Role for Forests Trees, Proceeding of the Regional TechnicalWorkshop, Khao Lak, Thailand , 28-31 August 2006. pp 5-24.

Miah, M.A.Q., S.A. Islam, M.A. Habib and M.G. Moula. 2014. Growth performance of Avicennia officinalis L. and the effect of spacing on growth and yield of trees planted in the Western coastal belt of Bangladesh. J. For. Res. 25(4): 835-838.

Nandy, P. 1989. Inn. Proc. First National Symposium, June 5-7, 1989. Plant Breeding in Bangladesh. pp. 230-252.

Nandy, P., M.J. Alam and M.R. Haider. 2004. Establishment of mangrove seed production area for Sonneratia apetala. J. Trop. For. Sci. 16(3): 363-368.

Nandy, P., Ahammad, R. 2012. Navigating mangrove resilience through the ecosystem-based adaption approach : lessons from Bangladesh, Sharing Lessons on Mangrove Restoration, Vol. 1, pp. 243254.

Saenger, P. 1987. Bangladesh Mangrove Afforestation Project. Shedden Pacific Pty, Limited, Melborns, Australia. pp. 62.

Siddiqi, N.A. and M.A.S. Khan. 1990. Growth performance of mangrove trees along the coastal belt of Bangladesh. Mangrove Ecosystems Occasional Papers. No. 8. UNDP/UNESCO REGIONAL MANGROVES PROJECT RAS/86/120. Thomson Press, Delhi. 5-14 pp.

Siddiqi, N.A. and S. Das. 1988. Effect of time and method of storage on the survival of uprooted keora (Soneratia apetala Buch-Ham) seedlings. Ind. J. Forest. 11(4): 326-330.

Siddiqi, N.A. 2001a. Mangrove Forestry in Bangladesh. Institute of Forestry \& Environmental Science: University of Chittagong, pp. 201.

Siddiqi, N.A. 2001b. Creating second rotation crops in the existing keora (Sonneratia apetala) plantations. In: Siddiqi NA, Baksha M W (eds), Mangrove Research and Development. Chittagong: Bangladesh Forest Research Institute, pp. 102-107.

Siddiqi, N.A. and M.A.S. Khan. 2000. Raising plantations of Phoenix paludosa - a mangrove palm in the coastal areas of Bangladesh. J. Asiat. Soc. Bangladesh (Sci.) 26(2): 259-264.

Siddiqi, N.A. 2002. Development and sustainable management of coastal plantations in Bangladesh. $J$. Asiat. Soc. Bangladesh (Sci.) 28(2): 144-166.

Woodroffe. 1992. Mangrove sediments and geomorphology" in Tropical mangrove ecosystems. Coastal and Estuarine Studies 41, A.I.Robertson and D. M. Alongi, Eds, pp. 7-41, American Geophysical Union, Wash, USA, 1992.

Zobel, B. and J. Talbert. 1983. Applied Forest Tree Improvement. Wiley, New York. pp. 505. 